This item was submitted to Loughborough's Research Repository by the author.

Items in Figshare are protected by copyright, with all rights reserved, unless otherwise indicated.

\title{
Exploring articulations of design activism
}

PLEASE CITE THE PUBLISHED VERSION

https://doi.org/10.21606/dma.2017.143

PUBLISHER

Design Management Academy

VERSION

VoR (Version of Record)

\section{PUBLISHER STATEMENT}

This work is made available according to the conditions of the Creative Commons Attribution-NonCommercial-ShareAlike 4.0 International (CC BY-NC-SA 4.0) licence. Full details of this licence are available at: http://creativecommons.org/licenses/by-nc-sa/4.0/

\section{LICENCE}

CC BY-NC-SA 4.0

\section{REPOSITORY RECORD}

Zajzon, Noemi, Erik Bohemia, and Sharon Prendeville. 2019. "Exploring Articulations of Design Activism". figshare. https://hdl.handle.net/2134/31840. 


\title{
Exploring articulations of Design Activism
}

\author{
ZAJZON Noémi*; BOHEMIA Erik and PRENDEVILLE Sharon \\ Loughborough University London, United Kingdom \\ * Corresponding author: n.zajzon@lboro.ac.uk \\ doi: $10.21606 /$ dma.2017.143
}

\begin{abstract}
Discussions on design activism generously embrace the activist ethos of designers, but are inconsistent in articulating how design activism makes a difference in relation to the various socially engaged design approaches generated. Committed to critically and transformationally engage with progressive socio-economic and political problems, the activist designer creates forms and situations within social processes. By mapping the fields of knowledge and concepts on which design activism draws, the paper attempts to bring an understanding of what informs Design Activism actions beyond the neoliberal paradigm. Drawing on the emerging discussions on design activism, the paper brings together articulations of design activism from scholars and design collectives to foreground the foundation for a more coherent understanding of design activism and a constructive dialogue within its community.
\end{abstract}

keywords: design activism; vision; social movements; grassroots innovation

\section{Introduction}

The paper presented is a stepping stone in a research part of doctoral studies. The workin-progress involves developing an understanding of contemporary design activist practices, how it takes place, and what are its implications for design practice and design education. Within this paper, we bring together the existing literature and emerging discussions on design activism; we explore the relationship between design activism and activist practices, and illustrate three case studies of how design activism might manifest.

By depicting the fields of knowledge and concepts on which design activism draws, and entering in a dialogue with its growing community, the paper brings together articulations of design activism from scholars and design collectives to understand its actions, goals and future potential beyond the neoliberal paradigm. 
While the $500^{\text {th }}$ anniversary of Thomas More's Utopia should have filled the world with hope and celebration ${ }^{1}$, the rise of populist right-wing wave and its impact on the socioenvironmental scene, raise a series of questions about the future we are moving towards. The acceleration of post-2010 'activisms', from the Arab spring to the Occupy movement, the anti-austerity protests in Europe and the global-justice movement, has been at the core of social movement debates raising the question whether it is driven by a new activist generation, one that has broken with prevailing utopias (Biekart \& Fowler, 2013; Glasius, Pleyers \& Biekart, 2013; Chomsky N., 2012; Chomsky, 2016; Klein, 2012). While the previous social movements were related to improving material interests such as economic wellbeing, the so-called "new social movements" are associated with immaterial interests, primarily social and cultural, underscoring quality of life, pacifism, individual selfrealisation and human rights (Habermas, 1982; Bucheler, 1995; Mayer, 2012). Activist waves often share the same infrastructure of networks that facilitate connections for participants sharing a common goal. Such networks give the possibility for new forms of collaborations to emerge bringing together civic energy, grassroots organisations, artists, architects, designers and other creative communities.

Meanwhile, design is branching away from the market toward creating 'alternative futures' through social practice. This intellectual expansion has generated a wave of alternative formulations of design, from "critical", "social", "activist", "disruptive" to "speculative", "speculative activist", "associative", "relational”, "transition" design, formulations that are descriptive about the process, and foreground the (relation to the) subject and not the object of design (Mazé \& Keshavarz, 2013). The myriad of terminologies strive to grab attention, while fragmenting the design community.

There seems to be a tension between the socially engaged design discourses developed in the comparatively privileged Western design community of the global North, and the discourses building on postcolonial theory, urging design to move away from the Eurocentric lenses, such as the series of events on political activism Climactic: Post Normal Design (2016), on Speculative Design in the "Real World" (2016) and the symposium on Decolonising Design (2016).

Within this new social turn (DiSalvo, 2016), design practice is engaging both in creative city politics such as 'hacking capitalism' adapted by the so-called 'creative class', as well as more heterogeneous spaces such as movements rooted in austerity urbanisms, antipoverty work, mobilisations against welfare reform, unemployment, politics of borders and immigrant rights, homeless activism, local exchange and other solidarity networks (Mayer, 2013). While entering into such contexts, the challenge for design remains to understand the social, and critically appreciate what 'making the social' means (DiSalvo, 2016). This concern of the design scholars has sparked various debates and generated discourses that have put the designer in a politically active subject, who can use its tools and skills to generate projects that would contribute to a society based on a different

\footnotetext{
${ }^{1}$ During 2016, London's first Design Biennale accompanied by a series of events and exhibitions explored the theme of Utopia: A year of Imagination and Possibilities at Somerset House in London. https://www.somersethouse.org.uk/press/utopia-2016-year-imagination-and-possibility
} 
value-system than the current establishment. This establishment being the 'process of neoliberalisation' (Design Culture Salon², 2017).

Although, the term neoliberalism continues to spark various heated debates, we will only consider it as one context in which the contemporary design activists operate. In Julier's narrative design activism seeks to 'contest' neoliberal processes and "searches for alternative models of practice" (Julier, 2013a, p.216). It acts on the neoliberal frameworks that shaped design culture and aims to "produce other futures" (Julier, 2013a, p.232). This embraces the activist ethos of design, but leaves us questioning what these 'other futures' and 'alternative practices' might be, and ultimately, confirms the importance for further research in how design activism changes design practice and its implications for the future of design education.

\section{Context of Design Activism}

\section{Activism(s) today}

Activism and design are becoming practices embedded within our everyday life by engaging with often similar matters of concern. Activism implies change and transformation and providing visibility to the larger public. Jordan (2001) suggests that contemporary activists take into consideration ethical issues which "may underpin or inform future societies" (p. 9). They use tactics such as "non-violent direct action, dis/organization, pleasure-politics, culture jamming and hacktivism" (p. 9). According to Jordan (2001), contemporary activism integrates many different social solidarities that challenge different social hostilities "in the context of radicalized forms of democracy" ( $p$. 10).

Being an activist involves often tackling a set of practices simultaneously to reach an overarching set of goals, to mobilise further, and get involved in movement activities. Understanding forms of participation and collective action has been a key element of social movement (Tarrow, 1993; Melucci, 1996; Polletta, 2002; Diani, 2004; Reiter, 2009; Graeber, 2009). Building on the concept of social movement explored by Diani (1992), della Porta and Diani (2006) suggest that "social movements are distinct social process" whereby actors, such as activists, "engaged in collective action: are involved in conflictual relations with clearly identified opponents; (they) are linked by informal networks; (and) share a distinct collective identity" (p. 20).

Such 'distinct social processes' have been studied extensively by scholars who have identified other important aspects such as: the motivations and collective identity (Melucci, 1995; Polletta \& Jaspers, 2001), understandings of value (Habermas, 1982; Biekart \& Fowler, 2013; Glasius, Pleyers \& Biekart, 2013; Mayer, 2013), vision and survival of social movements (Tilly, 1977) and framings within social movements (Benford \& Snow, 2000; Smith et al. 2016). More recently with the emergence of the 'new social

\footnotetext{
${ }^{2}$ The Design Culture Salons are occasional discussions and debates on the changing role of design in contemporary society, and the future of design culture, criticism, representation and practice https://designculturesalon.org/about/
} 
movements' increasing attention has been given to practical projects and the politics underpinning their actions (Yates, 2014).

\section{Vision}

In terms of vision, the debate is ongoing: movements rarely have one goal, but usually they have several goals linked together, which vary in scale, precision and its target. This problematic aspect of activist movements has been raised by Alex Williams and Nick Srnicek in their manifesto for 'life after capitalism' (2015). In this manifesto, they ascribe the 'no clear vision' to what they describe as 'folk politics'. They suggest that under the subsection of the Left there is this urgency to turn towards various forms of immediacy such as spatial immediacy, environmental and economic localism, but most importantly a temporal immediacy, which often prefers short-term vision over long-term strategic thought. Furthermore, conceptual immediacy and an emphasis on the emotion over the rational, the preference of the personal over the structural, and affect being favoured over the reason. These aspects and attitude to address social, political and environmental issues are just as relevant for design(activist) practices as they are for activist movements.

\section{From Dissensus to Consensus}

Finding the balance between dissensus and consensus or the route from dissensus to consensus, is a central theme within activism and a core debate of social movement scholars (Habermas, 1981; Graeber, 2009; Stringer, 2015)

Consensus means the agreement between the political and social parties to find the common interest of the community. Within the public sphere, Habermas considers consensus as the 'rationally motivated agreement' that is achieved once participants 'overcome their subjectively based views' but which presupposes the power differences between participants to be neutralised (Flyvbjerg, 2000). Neutralising these power differences for Rancière (2010) means that consensus reduces political difference to homogeneity, and objectifies the nature of any collective situations. With political differences Rancière refers to what people do that challenges the hierarchical order of a given set of social arrangements (Rancière, 2010; Fjeld, 2016).

Mouffe (2000) too argues for a democratic model, in which people can express themselves over an issue and recognise themselves as political subjects, but she agrees that a pluralist democratic model is only possible with a certain consensus. In her terms this is a 'conflictual consensus', and dissensus is important as it "makes visible, what the dominant consensus tends to obscure and obliterate" (Mouffe, 2007).

Within activist communities, and social movements, activists claim the consensus model has many flaws, as it may compromise demands by not discussing them. It is also suggested that consensus-based meetings are less efficient (Graeber, 2009; Stringer, 2015). Graeber (2009) considers consensus as a process that builds upon mutual respect and creativity and "which tries to make sure no one is able to impose their will on others and that all voices can be heard" (p. 303), even if no decision will be reached in the end.

Dissensus, on the other hand, disrupts the power structures of the social order. According to Rancière (2011) dissensus is based on ordering of the 'sensible', which reveals and includes the 'inadmissible', what might be excluded by consensus. While consensus deals 
with the redistribution of powers and negotiation, dissensus challenges the established framework of the perception. Graeber (2009) and Stringer (2015) suggest that by encouraging dissensus the possibility is given for conflicting views to play out. This enables everyone within the group to speak up and discuss, before they can move to a consensus.

\section{Awakening to the political}

While the political nature of socially engaged design has been mainly a concern of design scholars and researchers (Fry, 2003; DiSalvo, 2010; Mazé \& Keshavarz, 2013; Tonkinwise, 2010), recently there is a growing awareness within design activist practices taking the political agency on board (Wood, 2017; Mediations, 2016; Menu, 2016; Design or Disaster, 2017; Civic University, 2017).

Within this design activist community, the meaning-making activity attributed to design (Simon, 1988) blends research, critical thought, activism, design and architecture practice to engage with progressive social, economic and political issues. Such design activist collectives design processes and frameworks in which the role of the designer and architect is challenged, often taking a mediator's role within the participatory processes and engagement forms they create. These engagement forms have been strongly informed by the agonistic approach to participatory design and public spaces (Mouffe, 2008), and the encouragement for dissensus over consensus (Rancière, 2010). Particularly, aesthetic dissensus (Rancière, 2009), has radically influenced social design (Koskinen, 2016), engagement with the publics, placemaking with communities, and design for debates. Design scholars have built on these theories to consolidate the various political implications of design as a 'practice' (Ingram J., Shove, E. \& Watson M.,2007) engaging with the social dimensions of different futures (Mazé, 2014; Smith, R.C. et al. 2016) that evokes and engages with political issues and enables agonism (DiSalvo, 2010), disrupts the system (Markussen, 2011) creating 'alternative' futures (Julier, 2013a), and which designs for the marginalised (Björgvinsson, Ehn \& Hillgren, 2012) and the undocumented (Keshavarz, 2016).

\section{Relationship between Activism and Design Activism}

Arguing for a pluralism of value, Mouffe (2008) foregrounds the agonistic model for a public space where critical practices can visualise 'that which is repressed and destroyed by the consensus of post-political democracy'. Her call is for an awareness to engage with and envisage current societal issues in a political way as political questions are not merely solved by experts. Choosing between 'alternatives' involves taking decisions in political questions (Mouffe, 2008), and this is where engaging with the alternative different to the dominant system is political. She argues for the aesthetic dimension of the political, the symbolic ordering of the social, a similar understanding of the aesthetic order as Rancière. Aesthetic for Rancière means a particular regime of artistic practice, that introduces heterogeneous subjects within the field of experiences by disrupting the socio-culturally entrenched forms inhabiting the everyday world (Rancière, 2010; Markussen, 2013; Koskinen, 2016).

Building on Mouffe's political theory regarding agonistic spaces, DiSalvo (2010) distinguishes 'design for politics' from 'political design' to analyse examples of design for democracy. He argues, that while design for politics seeks to offer solutions for immediate 
needs by finding consensus, political design, recognises the inevitability of dissensus within society and aims to reveal the underlying issues behind initial perceptions by contesting and challenging the status quo, while enabling long-term impact. This definition of political design (DiSalvo, 2010) resonates with design activism, in the sense that design activism challenges the status quo and addresses the underlying issues behind what seems obvious.

While most design thinkers agree on the aspect that design(activism) should encourage more dissensus (Markussen, 2011; DiSalvo, 2010; Keshavarz \& Mazé, 2013; Fuad-Luke, 2017), some consider that design through consensus or a combination of both opens more opportunities for design activism (Julier, 2008; Meroni et al. 2013). However, in the actual practice of design collectives, it is not explicit how and why one would exclude the other. Therefore, more research is needed to understand how dissensus articulates design activist manifestations, and what are its implications within the contexts it intervenes.

\section{Design Activism}

Advocates of micro-utopias implemented in the everyday, the activist designer uses its tools and skills to generate projects that envision a society based on a different valuesystem than the current establishment. Thorpe (2008) recognises that designers fulfil an activist role, either being themselves activists or by being 'activists for hire'.

Departing from the most emerging socio-political and environmental tensions we face today, design activism creates situations that challenge power-relations and articulate new courses for actions. Compared to other design practices, design activism acts on the established frameworks to create "other futures" (Julier, 2013a, p.232). Within discussions on design activism (at the Design Culture Salon, 2017; Design or Disaster Symposium, 2017; Civic University at Tate Exchange, 2017) the established frameworks are constituted of neoliberal doctrine. However, there remains nascent research on how design activism puts pressure on these frameworks and what the 'alternative / other futures' would be. It seems, that striving to understand how design practice changes within the neoliberal paradigm leaves these discussions stuck: it misses to address the key problematics such as how design can contribute to positive transformational processes and what are the possibilities and realities of what design activism could do. What does it exactly mean to act on the dominant frameworks? Working towards this question, the next section brings together articulations and proposed frameworks from the existing literature in order to understand how design activism might achieve this.

\section{In pursuit of a definition}

Whether it comes to social design, participatory design, design anthropology or design activism, the place to start with is Victor Papanek's (1985) seminal text titled Design for the Real World. Papanek's work, that would underpin the global design activism movement of the $20^{\text {th }}$ century, originated in the early participatory design activism of 1960s Finland and the emergence of the pan-Scandinavian student design movement (Clarke, 2013).

The timeline of design activism traced through design history is long and has been put forward already by scholars (Fuad-Luke 2009; Thorpe 2011; Julier 2013a; Clarke 2013). 
Therefore, the focus of this section is to locate contemporary design activism by mapping the scholarly and informal definitions, identify its current relevance and how it makes a difference in the field today.

\section{Design movement or design approach?}

Often discussed as a design reform movement (Fuad-Luke, 2009; Julier, 2013ab) and a design movement (Clarke, 2013), design activism emerged as a result of the processes of change of advanced industrialisation and globalisation, and the discourse and practices of individuals and groups who wanted to find alternative ways to their practice from the mainstream industry (Julier, 2013ab). Based on social processes and social movements (Cetin, 2016; Thorpe, 2011) and borrowing from concepts of protest and resistance, design activism calls for change through unconventional methods, particularly through disruption of routine practices, systems and structures of institutionalised, or dominant power (Thorpe, 2008). Contemporary design activist impulses are trying to self-consciously respond to neoliberal circumstances, and "develop new ways of working that coincide with geopolitical, economic, and environmental crises" (Julier, 2013b, p.226).

Historically, design activism is not limited to neoliberal societies. It has taken place in other forms of political and economic structures such as during the cold war in the communist countries. It continues to exists today in countries which may not have neoliberal governments, most probably under different labels such as social or civic activism. Also, understanding it as a movement implies that design activism has a beginning and an end in a specific context, which then should be appreciated within that context.

For Fuad-Luke (2009, p. 29) design activism is "design thinking, imagination, and practice applied knowingly or unknowingly to create a counter-narrative aimed at generating positive social, institutional, environmental and/or economic change". In the past, FuadLuke (2009) used design activism as an umbrella term to encompass various design approaches. More recently, he (Fuad-Luke, 2017) distinguishes design activism from social design through its teleological orientation, and the way it uses consensus and dissensus. While social design has a more predefined purpose within the neoliberal agenda, and seeks public and social good within the dominant system, design activism focuses on 'alternatives' that challenge the existing power structures and relations (Fuad-Luke, 2017). In a recent essay on the teleological orientations of design activism, Fuad-Luke (2017) examines the framing of design activism in comparison to social design and highlights differences between them within the language characteristics, their goals, and how they use consensus and dissensus.

Meanwhile, the Social Design Futures research study (Armstrong et al., 2013) lists design activism as an approach to social design defining it as being:

more explicit in its political intentions than Design for Social Innovation and Socially Responsive Design. It includes the creation of artefacts and experiences associated with political discussion and protest, but also results in designs that intervene into everyday lives while raising political consciousness concerning collective challenges (Markussen 2013, Julier 2013). It usually sits outside commercial or governmental structures and 
works through settings such as grassroots activities, community action or pressure groups. (Armstrong, Bailey, Julier, \& Kimbell, 2013)

Within this definition design activism becomes another 'voice' of the social design discourse. Chen et al. (2015) and Bugali et al. (2016) suggest that social design itself failed to establish an explicit definition. In a discursive analysis of the 'multivocality' within social design, Bugali, Fairburn and Halsall (2016) raise awareness about the presuppositions ${ }^{3}$ within the field and argue for a more critical approach in order to understand social design actions.

\section{Locating Design Activism in the field}

The various approaches to design activism and narratives around it, confirm that there is an enthusiasm to return to understanding what design activism can offer, but they also reveal that these approaches and framings are not discussed in relation to each other. The definitions and goals of design activism mentioned above seem to all agree that design practice and design research needs to adopt a more critical approach to address the political and ethical tensions of the social futures it wants to address.

\section{Frameworks}

While there is no clear definition of what design activism is, the following frameworks have been proposed by scholars that discuss design activism:

- $\quad$ in relation to other socially engaged design approaches (Markussen, 2014; FuadLuke, 2017),

- the context in which it operates (Fuad-Luke in Walker et.al 2013; Julier, 2013b), such as when dealing with processes of neoliberalism,

- $\quad$ and its implications to design culture (Julier, 2013b).

These frameworks attempt to provide orientation within the narrative around design activism. Nevertheless, they miss to establish a dialogue with the context and conditions of activism or the grassroots movements where often definitions position design activism.

Based on the Design History Society 2011 conference, Fuad-Luke (Walker et.al 2013) develops a meta-framework in which dissensus, consensus and transitional practice transform the existing system within neoliberal societies. Within this meta-framework Fuad-Luke distinguishes design activist practices that work outside the existing paradigm, within the existing paradigm and on the edge of the existing paradigm ${ }^{4}$. While these

\footnotetext{
${ }^{3}$ Bugali, Fairburn and Halsall (2016) list a number of presuppositions in the field of social design.

${ }^{4}$ Within the meta-framework Fuad-Luke (Walker et.al 2013) lists examples for design activist practices that work outside the existing paradigm (such as the work of Markussen, Dunne and Raby, Gaspar Mallol's frictions, Walker's propositional artefacts), within the existing paradigm (Design Council, Architecture for Humanity 2006, Pilloton 2009, Julier 2011, Meroni 2007, Wood 2008, Mattelmaki and Visser 2011) and on the edge of the existing paradigm , such as quiet activism through craft practices (Hackney 2011), craftivism (Patel 2011), co-designing as making (Neuberg and Bowles 2011) and 'open design' (van Abel 2011).
} 
categories can be useful aspects to map the activist efforts of various design practices, the umbrella term covering the examples he provides generalises design activism.

Meanwhile, the conceptual framework proposed by Julier (2013b) discusses design activism in relation to the processes of neoliberalism, and how, within the shift 'from' design culture 'to' design activism, design activism appropriates four key themes:

intensification - described as a density of designerly intervention; coarticulation - labelled as the marrying up of concerns or practices in a way that strengthens both; temporality - thought of as the way that speed, slowness, or even open-endedness may be dealt with; territorialisation viewed as the scale through which responsibility is conceived. (Julier, 2013b, p. 227)

With these concepts, he sets the time and space for design activism to intervene in the social, political and environmental modes of existence as a 'movement' that is 'broad in its scope and aims', and which intersects with 'social design, community design, participatory design, and critical design' (Julier, 2013, p.226), 'cocreation and sustainable design' (Julier, 2013a, p.146) However, these intersections are not discussed in relation to each other.

Furthermore, Julier (2011) distinguishes two design activist approaches: one that addresses massive change and another which emerges from within communities. Example of the former which tries to address global political issues with impact on a global scale are the Massive Change: A Manifesto for the Future Global Design Culture (Mau, 2004) and the Design Like You Give a Damn: Architectural Reponses to Humanitarian Crises (Architecture for Humanity, 2006). The later aims to support initiatives which stress the importance of social practices and where designers draw on expertise from local challenges as part of a world view on responsibility. Here the design activist becomes a facilitator, the listener who recognises the needs and aspirations of the community (Julier, 2011; Manzini, 2014). Focusing on transformation of the use of resources that support everyday life, these 'social innovations' are characterized by localism, small scale interventions and build on the crafts and capabilities of the local people, gearing social learning towards sustainability (Julier, 2011).

It is important to notice, that with this second approach Julier takes design activism into the social innovation journey. However, scholars such as Markussen (2014) and Fuad-Luke (2017) have already argued that design activism differs from social innovation. This also suggests that the views have not been consistent. The reason for this might be that: 1 ) within this new social turn design continues to be dematerialised; 2) social design and social innovation adapts various definitions depending on the context or the network it represents (e.g. DESIS); 3) the recent enthusiasm for adopting Rancière's aesthetic dissensus and Mouffe's agonistic pluralism, has conflated the vocabulary of design shifting the focus from aesthetic and function to the social forces (Koskinen, 2016).

Within the discourse of the social innovation journey, design activists are considered part of the Creative Community, defined by Meroni and Manzini "as people who cooperate in inventing, enhancing, and managing viable solutions for new (and sustainable) ways of living" (Manzini, 2014, p. 62). When offering alternative 'solutions' to the problems 
addressed, the social innovation journey seeks consensus to co-create an infrastructure with different stakeholders.

To conclude from these ongoing debates, it seems that while social innovation aims to empower deeper democracy, design activism is trying to address the underlying tensions of democracy, often acting more as a form of enquiry, than providing solutions; being rather a state of mind examining transformative politically charged actions, than rushing to implement the idea in a business model.

More importantly, there seems to be a disconnection between the discursive framings proposed to understand design activism and how design activism is articulated in practice. As a practice, it is often situated within the grassroots initiatives, pressure groups and community design projects (Armstrong et al. 2013). To understand the dynamics and motivations of grassroots initiatives the grassroots innovation movement literature (Smith et al. 2016) provides a useful framing informed by social movement literature. Within social movement studies, concepts of framings are key in understanding how collective action is informed by the production of ideas and meanings that create "bonds of solidarity'; how they inform 'alternative visions' and open up 'spaces for participation and action' (Smith et al. 2016). Smith et al. (2016) differentiates grassroots activities through contexts, framings, spaces and strategies, and pathways. This analytical framework could inform the spaces of actions of contemporary design activism, the 'pathways' design activism is proposing for positive transformation, and how attitudes within the design activist collectives are changing design practice. Bringing the grassroots innovation literature into this conversation, we seek to foreground the foundation for a more coherent understanding of design activism and a constructive dialogue within its community.

\section{Forms of Design Activism: A Conversation between Activism and Design}

Activism has different connotations and dynamics varying from the capitalist countries of the global North to the Eastern European Block and the global South. Similarly, design activism has been taking place in various forms around the world, not necessarily under the label of 'design activism'.

The Global Design Activist Survey conducted by Kaygan and Julier (2013) has started a conversation by collecting different understandings of contemporary design activism from designers, design scholars and historians. In the survey, they asked 1) how design activism has impacted design culture locally, and 2) what they found as a key challenge for design activism in that particular region.

Most responses shared the activist ethos of counterculture providing an alternative framework to the established system and empowering the marginalised, and that design activism acts more like an 'activism' on design culture. Beyond the enthusiasm for such an 'activism', however, there seems to be an overarching concern about design activism being surrendered by various too many discourses, tactics, styles or tools which, they suggest, might obstruct bringing meaningful change in the local context where design activists intervene. 
In India design activism encourages design to be more self-reflexive beyond its connection with the nation-state and markets, while in Turkey design activism has mobilised design knowledge introducing the products and practices of marginalized communities. In Beirut design activism enabled an alternative framework of the practice to emerge locally, one that is motivated by critical inquiry and meaningful exchanges in the public sphere. It acts as counter-culture movement and more recently as a close ally to society in Denmark, and contributes to redefine the public role of design influencing the developmental agenda in Cape Town. Furthermore, design activism is influential in the field of ideas activating citizen's participation in Barcelona, and it generates citizen consciousness and educates the public in responsible consumption in Bogota, Colombia.

Finally, Kaygan and Julier (2013) conclude that design activism develops cooperation within the frameworks of groups, communities, even institutions.

The stories in the survey provide only a brief insight into the local context and meaning of design activism, and some of the articulations even share similarities with what others would consider social innovation. Overall, the responses reveal more about the thresholds where design activism intervenes, and where its future opportunities may lie. The survey foregrounds this important conversation between activism and design. Taking this investigation further, we argue for the importance of more in depth research on how design activism manifests and with what methods and frameworks it works to challenge the dominant system for a positive transformation.

\section{Articulating Design Activism}

Solidarity and transgression, collective and action, are the twins of activism. (Jordan, 2001, p.12)

To understand design activism actions, this part of the paper will briefly portrait the ethos that is driving design activist practices.

The interventions and participatory processes used within design activist practices are informed by the position they take such as critical feminist economics, situationist psychogeography, postcolonial theory or radical democracy. Methodologies here include co-design and participatory design. According to Lenskjold, Olander and Halse (2015) these are not normalised yet and are highly interdisciplinary and subject to experimentation. This interdisciplinary exploration is paired with an eco-socio-political consciousness emerging from the precarious economic condition that has influenced the designer's attitude towards the subject of design and the responsibility they see designers should take in society.

While they are taking the political agency of design on board, there seems to be an urge to act on the immediate problems that the current social, political and economic scene is causing. A similar tendency towards the political awaking is seen by Srnicek and William (2015) more as political common sense and not a political moment, a horizon of understanding where political action and tactics can be conceived, but which might not be a constructive position for envisioning a better future. The visionary-dilemma, or favouring short-term goals over long-term thinking, however, in the case of design activist practices is arguable. Most of these collectives emerged as a result of an era of austerity, 
young design graduates struggling to find secure employment as experienced practitioners (Wood, 2017; Menu, 2016; Design or Disaster, 2017). This awareness of the current economic and political conditions shapes the design activist's methods and fuels commitment to critically and transformationally engage with current progressive sociopolitical issues, such as increased borders, structural racism, economic inequality or the erosion of the welfare state. Within design activist projects change has many dimensions, and it varies from small symbolic to global scale.

Design activism is heavily connected to urban design movements and planning (Mayer, 2013), as well as architectural practices that use design as a tool for collective benefits (Wood, 2017). Here design activism emerges as a way to address social and spatial issues. Such practices combine strategies to reorient subjectivities and articulate claims for a transformational change for the marginalised within the urban or address other tensions fuelled by neoliberalism.

For example, these can take form as occupying land and setting up spaces for knowledge and skill exchange, repair cafes, participatory pedagogy and co-designing with communities for local ecosystems and exploring forms of collective governance (AAA ${ }^{5}$ at Civic University, 2017). These strategies make things visible, problems more tangible and give people access to these forces and roles of architecture and design. While they produce slow transformation on the local level, there is an emerging question coming both from critiques (Wood, 2017) and the collectives themselves (Civic University, 2017; Design or Disaster, 2017), whether these strategies and forms of design engage enough with the opportunities available for the change design activists claim to address.

\section{Case Studies}

The three selected case studies included below illustrate how design activism might manifest and how it can act on the dominant systems. Transgression is one of the key elements of activism (Jordan, 2001) and also present in design activist interventions. It means an action that goes against a rule, challenges the status-quo, thus it involves some change in the normal state of affairs. The case studies illustrate how design activism might disrupt power structures by creating 'alternative routes' through use of storytelling with in architectural processes (La Rivoluzione Delle Seppie), by incorporating a strategic satire within design interventions (Two-Tailed Dog Party) and lastly by utilising collaborative formats to design for disagreement (Planning for Protest).

\section{Conversations that transgress the current political system}

One way to challenge the status quo of the system, is the way Stories from the front ${ }^{6}$ engages with the refugee-crisis in the region of Calabria of Southern Italy. The initiators, La Rivoluzione Delle Seppie, are an interdisciplinary practice formed by a group of experts from different backgrounds, who explore ways to address topics such as education (lack

\footnotetext{
${ }^{5}$ atelier d'architecture autogérée / studio for self-managed architecture ( $\left.a a a\right)$ is a collective platform which conducts explorations, actions and research concerning urban mutations and cultural, social and political emerging practices in the contemporary city.

http://www.urbantactics.org/research/r-urban/

${ }^{6}$ http://larivoluzionedelleseppie.org/

https://www.kickstarter.com/projects/827906908/stories-from-the-front
} 
of), immigration and integration. They explore methods that instigate conversations that transgress the current political system in Italy; and examine playful ways to address pressing issues, using storytelling, puppet cinema, communal cooking in the case of Stories from the front.

Designed in the format of a series of workshop-experiences it explores the geographical, the social, and cultural to highlight and bridge the clash between African and European cultures caused by recent migration (Figure 1). Within the socio-political agenda they are developing, the architect / designer becomes someone who facilitates strategies, convenes with various actors and most importantly links marginalized communities to those in power.

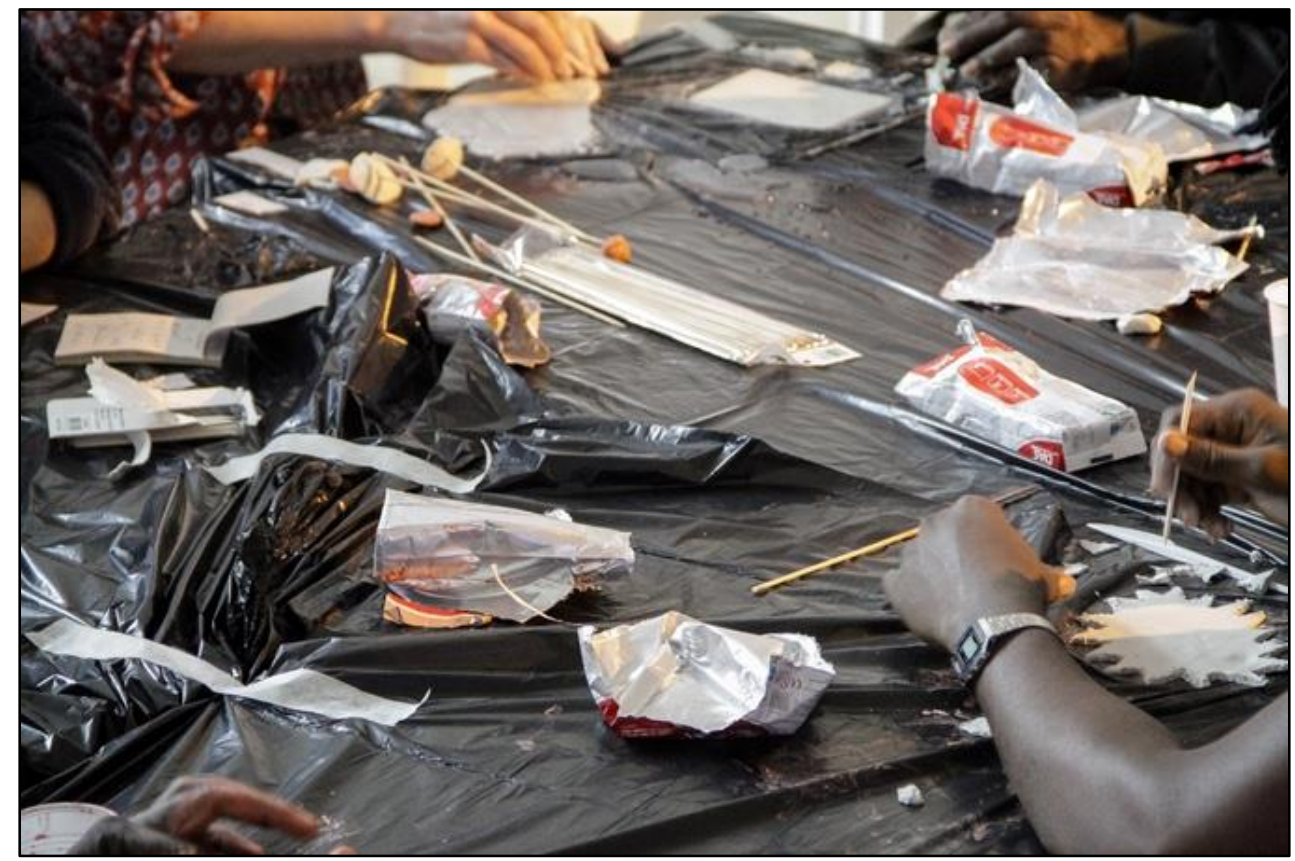

Figure 1 Busy minds at work. Building the Storytelling Studio. Photo: Stories from the front, 2016

A slightly similar initiative involving asylum seekers in various activities, is the QuerciaLAB, a community economies research and resource centre set up by the collective called Brave New Alps ${ }^{7}$ in Rovereto, Italy. The collective's practice lies at the intersection of communication design, spatial interventions, DIY and critical pedagogy. The vision of QuerciaLAB is to grow into 'an interface that through making, research and cultures foster the creation of alternative socio-economic relations between old and new inhabitants of the region and beyond ${ }^{\prime 8}$, most recently. At the core of their work are values of the commons and mobilising through making, research and design education.

\footnotetext{
${ }^{7}$ https://www.salto.bz/de/article/08032017/design-ist-mehr-als-form-und-farbe ${ }^{8}$ http://www.brave-new-alps.com/news/
} 


\section{Strategic use of humour within interventions}

Activism that integrates satire, the absurd and other forms of humour is often a successful tool to mobilise people in Hungary for example.

Humour is an important tool for disruption, subversion, and central in the formation of the social and political identity is the active, strategic use of humour. It is tied to the local context and can only make sense to the people who are familiar with the references it makes. While it is arguable to say that its use in social movements is universal, there are several examples showing how satire, humour and the absurd are engaged in the construction of political subjectivities challenging the norms of the given social order (Karakayali \& Yaka, 2016; Weaver et al. 2016). Such an example is the work of the fringe political party called the Two-Tailed Dog Party (MKKP) ${ }^{9}$.

During 2016, MKKP has raised 29 million HUF ( $£ 80000)$ from citizens in just two weeks to launch a billboard campaign countering Prime Minister Victor Orbán's controversial antiimmigrant referendum on a mandatory resettlement quota. This initiative mobilized Hungarian NGOs who urged the public to boycott the referendum by either not attending or discarding the vote by ticking both 'yes' and 'no' on their ballots. The 'deadly serious' billboard designs that covered the country with slogans satirising the government's xenophobic billboards (Figure 2, Figure 3), triggered other smaller opposition liberal parties to initiate small scale billboard campaigns calling on people not to go to vote. Most Hungarians indeed stayed away or gave invalid or unclear answers misleading the question. The result was that the referendum failed, given that the number of valid votes did not reach the threshold of $50 \%$.

Through their often humorous street art, graffiti, stencils and poster formats, MKKP provides stark criticism of company policies, the state of Hungarian railroads, sabotage large billboards signs while providing a meta-humour that mobilises both the local and the Hungarian diaspora.

${ }^{9}$ https://www.theguardian.com/world/2016/jan/06/hungary-two-tailed-dog-viktor-orban 


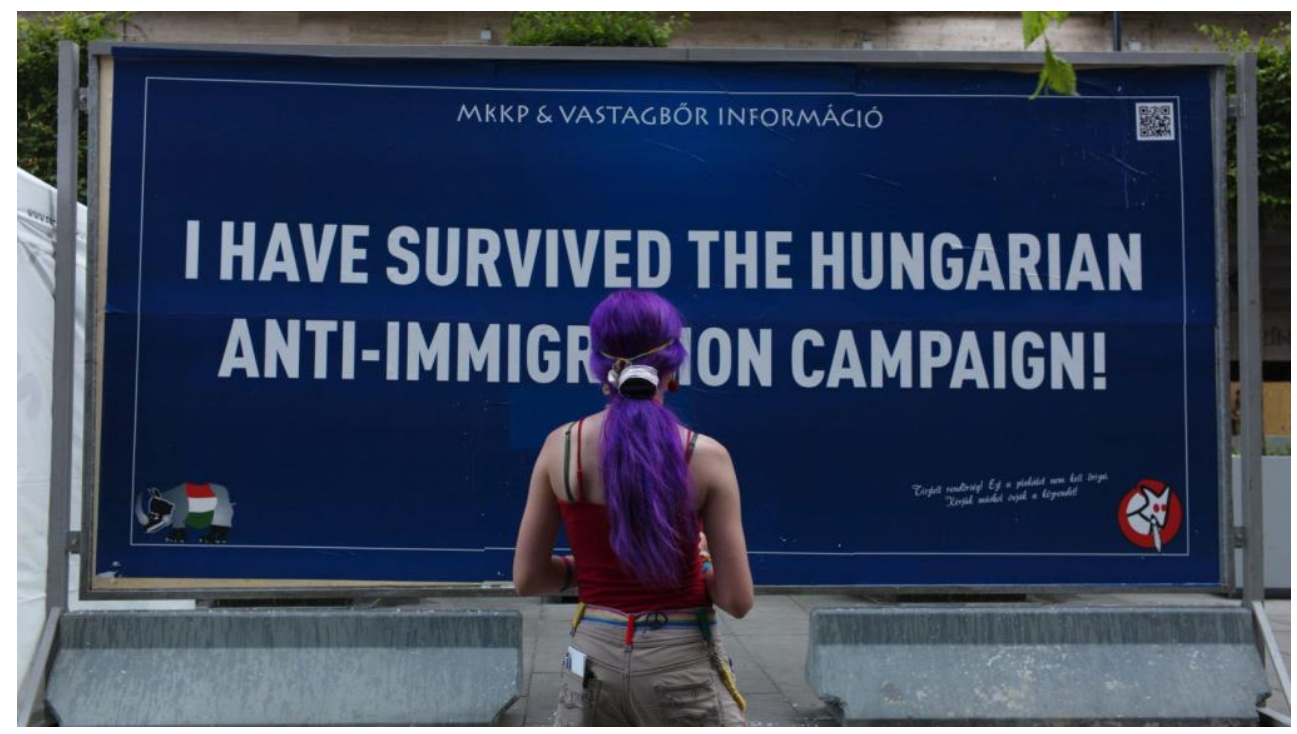

Figure 2 Counter-billboard campaign to Viktor Orbán's anti-immigration referendum. Photo: Béla Szandelszky (Karáth, 2016)

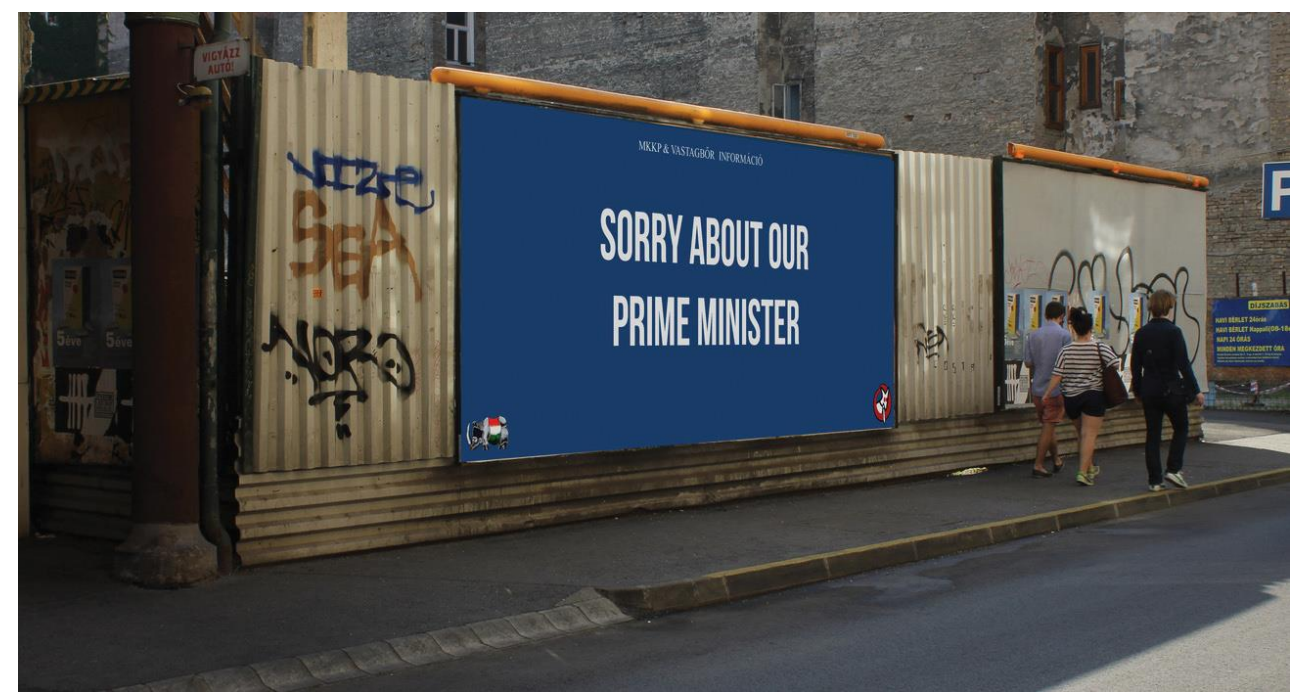

Figure 3 Counter-billboard campaign to Viktor Orbán's anti-immigration referendum. Photo: MKKP (Földes, 2015)

\section{Collaborative platforms for designing forms for disagreement}

While developing networks design activist practices often join forces in collaborative projects, or happen to respond to similar provocations in the frame of large scale events. Such an example is Planning Protest, a project with 12 collectives participating as part of the Lisbon Architectural Triennale 2013, which explored the social and architectural 
definitions of protest in light of the 2008 financial crisis. The aim was to understand how public spaces shaped the subsequent global protests, by gathering proposals from twelve architectural offices in twelve global cities that examine the role of architecture in defining, or limiting the flow of protest within their respective contexts. The outcome was an exhibition and a publication that compiled the proposals in the format individual cards. Such projects could intervene and inform the built environment, but what often happens with projects curated as part of large scale events, is that the content and insights from projects remain stuck in a well-designed publication.

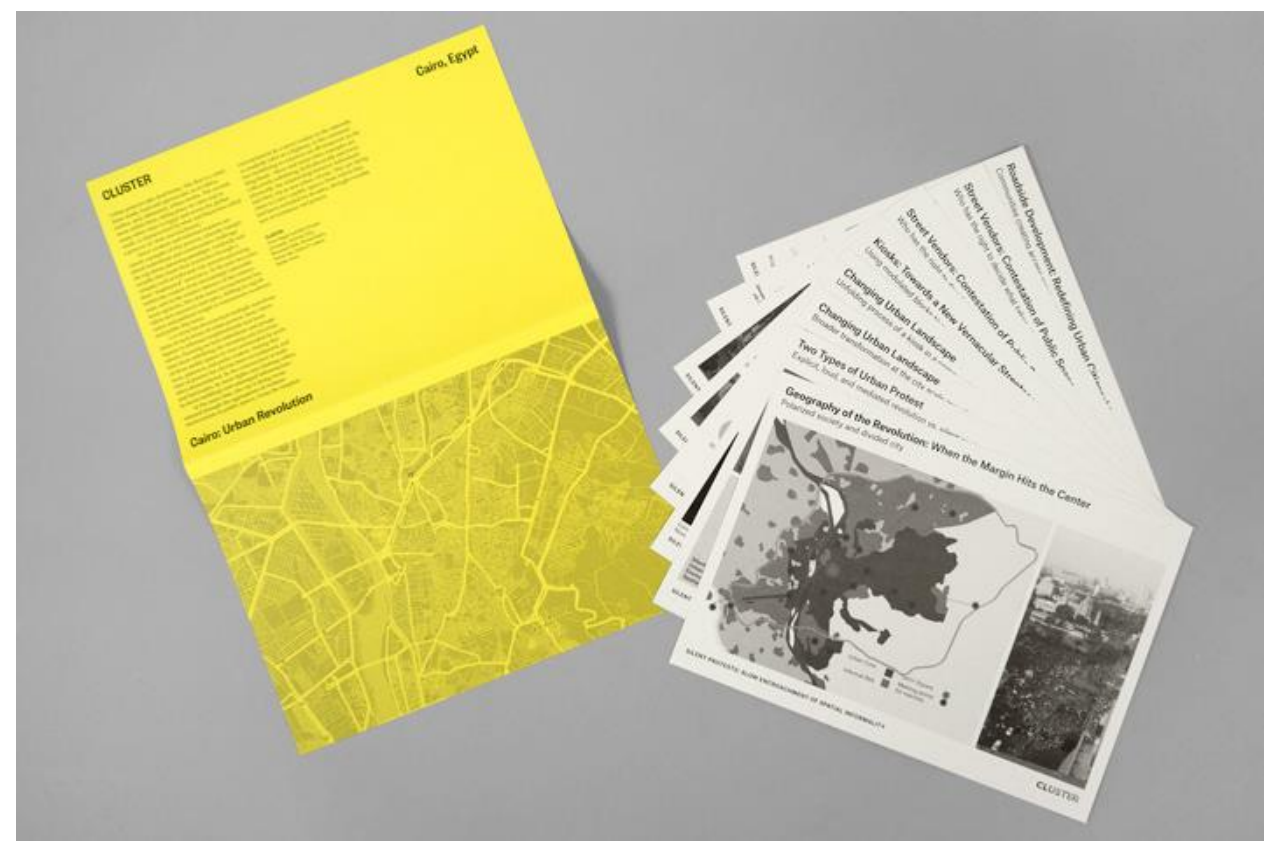

Figure 4 Publication of Planning for Protest (Lisbon Architecture Triennale, 2013)

\section{Conclusion}

While there are various understandings of design activism, views are inconsistent and discourses are often disconnected from the local dynamics and meanings of activism. Drawing on contemporary notions of activism and discussions within social movement theories we aimed to further the dialogue between activism and design in order to consolidate understanding, the shortcomings and future opportunities of contemporary design activism.

Literature and discussion within activist and design activist communities confirm that they both are working towards structures which will support the development of more equal and ethical forms of societies. While contemporary activist impulses are merging into new definitions of a moral society (Jordan, 2001), design activist collectives are curating new forms of design within social practices finding inspiration in 'alternative futures' that deviate radically from the current establishment.

Just as activism is not proposing a plan in the sense of a utopia, not even a blueprint by which we could achieve our immediate goals, design activists shy away from envisioned 
futures. Instead they design situations, spaces for solidarity networks alternative to the dominant system.

Beyond the strong commitment and dedicated explorations to critically and transformationally engage with issues emerging from the precarious condition, there is also a strong sense of developing an identity as a collective, a collective-lifestyle independent from the current establishment. Identity has a critical role in mobilising and sustaining solidarity, commitment and participation, and collective identities among activists are also used as a strategy to mobilise groups around a certain issue (Polletta \& Jasper, 2001). In understanding design activist collectives, it is important to recognises the risks of being non-conformist, a dissenter, and its economically precarious condition, as well as its potential to pressure the establishment and contribute to positive transformation.

From the three case studies presented here, the Two Dog-Tailed Party has managed to fundamentally change something that the government wanted to impose on Hungary. Quercialab and Stories from the front engage with the tensions asylum seekers face by subverting the existing power structures. Working from the margins towards centralised issues, addressing the underlying matters of concern, design activism can redirect the narrative, empower causes of the marginalised and engage communities in articulating possible future visions. While there are many similar projects and cross-collective collaborations, the question of how to sustain such initiatives and scale up positive transformation remains a question for a future research.

By mapping the debates around design activism from the past decade, we started working on a framework that could help understand the ambitions and processes of design activist collectives committed not to depend on the dominant system in society. This is necessary for two reasons. First, designers committed to address progressive social, political and environmental issues have changed the attitude towards the subject of design, and are changing design practice. Second, the growing network of design activist collectives are building processes and frameworks to challenge power structures imposed by the 'dominant' systems. Better understanding of these processes will provide a knowledge which can contribute to further develop design activist practices as well as design education to inform future design activists.

\section{References}

Armstrong, L., Bailey, J., Julier, G., \& Kimbell, L. (2013). Social Design Futures: HEI Research and the AHRC.

Benford, D. R. \& Snow, A. D. (2000). Framing Processes and Social Movements: An overview and Assessment. Annual Review of Sociology, 26, 611-639.

Biekart, K. \& Fowler, A. (2013). Transforming Activisms 2010+: Exploring Ways and Waves. Development and Change, 44(3), 527-546.

Björgvinsson, E., Ehn, P. \& Hillgren, P.-A. (2012). Agonistic participatory design: working with marginalised social movements. CoDesign, 8 (2-3), 127-144.

Brave New Alps (2012). Designerly Becomings - Alternative Value Practices within Design. In: MATOS, S. \& ROSSI, C., eds. Designing Alternatives symposium, 2012 Edinburgh College of Art p. 13-20. 
Bugali, H., Fairburn, S., \& Halsall, R. (2016). In pursuit of the voices within social design discourse. In the Proceedings of training art and design researchers for participation in public space (TRADERS): mediations; art and design agency and participation in public space, 21-22 Nov 2016, London, UK. London: TRADERS, pp. 163-173. Held on OpenAIR [online]. Retrieved from: http://openair.rgu.ac.uk.

Cetin, O. D. (2016). Design activism from the past to present: A critical analysis of the discourse. Paper presented at the Making Trans/National Contemporary Design History [=ICDHS $2016-10^{\text {th }}$ Conference of the International Committee for Design History \& Design Studies], Taipei.

Chen, D. -S., Cheng, L. -L., Hummels, C., \& Koskinen, I. (2015). Social design: An introduction. International Journal of Design, 10(1), 1-5.

Clarke, A. J. (2013). "Actions Speak Louder". Design and Culture, 5(6), 151-168.

Climactic: Post Normal Design (2016). Exhibition at The Miller Gallery at Carniege Mellon University. Retrieved from https://www.design.cmu.edu/content/climactic-post-normal-design.

Changing the Change (2008). Design, Visions, Proposals and Tools. Proceedings. Retrieved from http://www.allemandi.com/university/ctc.pdf.

Chomsky, N. (2012). Occupy (Vol. 1): Zuccotti Park Press.

Chomsky, A. (2016). Will the Millennial Movement Rebuild the Ivory Tower or Be Crushed by It? Retrieved from http://www.tomdispatch.com/blog/176143/.

Civic University (2017). The Art of Being Civic. Symposium at Tate Exchange. Retrieved from http://www.tate.org.uk/whats-on/tate-modern/tate-exchange/symposium/civic-university/artbeing-civic.

Decolonising Design (2016). Retrieved from http://www.decolonisingdesign.com/

Design or Disaster (2017). Make work work! Symposium at Free University Bolzano. Retrieved from http://designdisaster.unibz.it/2017/.

Designing Alternatives: A Symposium of Contemporary Radical Design Practice. In: MATOS, S. \& ROSSI, C., eds. Designing Alternatives symposium, 2012 Edinburgh College of Art. Retrieved from http://www.eca.ed.ac.uk/sites/default/files/documents/research/Designing\%20Alternatives\%20 booklet.pdf

Diani, M. (1992), The concept of social movement. The Sociological Review, 40, 1-25. doi:10.1111/j.1467-954X.1992.tb02943.x.

Diani, M. (2004). Networks and Participation. In The Blackwell Companion to Social Movements Edited by David A. Snow, Sarah A. Soule, Hanspeter Kriesi. Blackwell Publishing. 339-259. Retrieved from http://voidnetwork.gr/wp-content/uploads/2016/09/The-Blackwell-Companionto-Social-Movements-Edited-by-David-A.-Snow-Sarah-A.-Soule-and-Hanspeter-Kriesi.pdf

DiSalvo, C. (2009). Design and the Construction of Publics. Design issues, 25(1), 48-63.

Disalvo, C. (2010). Design, Democracy and Agonistic Pluralism. Proceedings of the Design Research Society Conference 2010, Montreal, 366-371.

Disalvo, C. (2012). Adversarial design, The MIT Press.

DiSalvo, C. (2016). Collectives in the Making: Design Research as Social Practice. LDDC Talk at RCA.

della Porta, D. \& Diani, M. (2006). Social Movements. Retrieved from https://www.hse.ru/data/2012/11/03/1249193172/Donatella_Della_Porta_Mario_Diani_Social_ Mov.pdf

Fjeld, Anders. (2016). Rancière antimaquiaveliano: cartografía estética, sitios de inconmensurabilidad y procesos de experimentación. Revista de Estudios Sociales, (55), 151162. https://dx.doi.org/10.7440/res55.2016.10. Retrieved from http://www.scielo.org.co/scielo.php?script=sci_arttext\&pid=S0123-885X2016000100013

Földes, A. (2015). Óránként egymillió jön be a vicces ellenplakátkampányra, annyira kiakasztotta az embereket a kormány. Retrived from 
http://index.hu/belfold/2015/06/09/orankent_kap_egymilliot_a_ketfarku_kutyapart_hogy_a_ko rmany_ellen_plakatoljon/

Flyvbjerg, B. (2000). Ideal Theory, Real Rationality: Habermas Versus Foucault and Nietzsche. Paper for the Political Studies Association's 50th Annual Conference, The Challenges for Democracy in the 21st Century. London School of Economics and Political Science, 10-13 April 2000.

Frediani, A. A. (2016). Re-imagining Participatory Design: Reflecting on the ASF-UK Change by Design Methodology. Design Issues, 32(3), 98-111.

Fry, T. (2003). Design and the Political: Hot Debate. Design Philosophy Papers, 1(6), 361-362.

Fuad-Luke, A. (2009). Design activism: beautiful strangeness for a sustainable world, Routledge.

Fuad-Luke, A. (2017). Design Activism's teleological freedoms as a means to transform our habitus. Retrieved from http://agentsofalternatives.com/?p=2539.

Graeber, D. (2009). Direct Action. An Ethnography. AK Press UK.

Glasius, M., Pleyers, G. \& Biekart., K. (2013). The Global Moment of 2011: Democracy, Social Justice and Dignity. Development and Change, 44(3), 547-567.

Halse, J. (2013). Ethnographies of the Possible. Design Anthropology: Theory and Practice, 180-96.

Habermas, J. (1982). New Social Movements. Telos, 1981(49), 33-37.

Ingram J., Shove, E. \& Watson M.(2007). Products and Practices: Selected Concepts from Science and Technology Studies and from Social Theories of Consumption and Practice. Design Issues, 23(2), 3-16.

Jordan, T. (2001). Activism! REAKTION BOOKS.

Julier, G. (2008). Design Activism as a Tool for Creating New Urban Narratives. In: Changing the Change, Turin, 2008. Proceedings... Turin, p. 813-822.

Julier, G. (2011). Political economies of Design Activism and the public sector. NORDES 2011. Helsinki.

Julier, G. (2013a). Introduction. Material Preference and Design Activism. Design and Culture, (5)2, $145-150$.

Julier, G. (2013b). From Design Culture to Design Activism. Design and Culture, (5)2, 215-236.

Karáth, K. (2016). Hungary is the latest country to lash out at the EU by calling a controversial referendum. Retrieved from https://qz.com/723542/hungary-is-the-latest-country-to-lash-outat-the-eu-by-calling-a-controversial-referendum/

Kaygan, H., \& Julier, G. (2013). Global Design Activism Survey. Design and Culture, 5(2), 237-252.

Keshavarz, M., \& Mazé, R. (2013). Design and Dissensus: Framing and Staging Participation in Design Research. Design Philosophy Papers, 11(1), 7-29.

Keshavarz, M. (2016). Design-Politics. An Inquiry into Passports, Camps and Borders. Doctoral Dissertation in Interaction Design. Malmö University. Available athttp://www.mahmoudkeshavarz.com/works/design-politics/

Karakayali, S., \& Yaka, Ö. (2016). Humor, Revolt, and Subjectivity. In A. Oberprantacher \& A. Siclodi (Eds.), Subjectivation in Political Theory and Contemporary Practices (pp. 203-218). London: Palgrave Macmillan UK.

Klein, N. (2012) 'Why Now? What's Next? Naomi Klein and Yotam Marom in Conversation about Occupy Wall Street', The Nation January. Retrieved from http://www.thenation.com/article/165530/why-now-whats-next-naomi-klein-and-yotammarom-conversation-aboutoccupy- wall-street/.

Koskinen, I., \& Hush, G. (2016). Utopian, Molecular and Sociological Social Design. International Journal of Design, 10(1), 65-71.

Koskinen, I. (2016). Agonistic, Convivial, and Conceptual Aesthetics in New Social Design. Design Issues, 32(3), 18-29. doi:10.1162/DESI_a_00396. 
Knutz, E., Markussen, T., Thomsen, S. M. r., \& Ammentorp, J. (2014). Designing for Democracy: Using Design Activism to Re-negotiate the Roles and Rights for Patients. Paper presented at Design Research Society 2014.

Lamadrid, M.C. (2013). Change for Social Design, The Social Design Toolkit. Retrieved from http://www.thesis.mlamadrid.com/?page_id=4 .

Lenskjold, T. U., Olander, S., \& Halse, J. (2015). Minor design activism: promoting change from within. Design Issues, 31(4), 67-78.

Lisbon Architecture Triennale (2013). Planning for Protest. Retrieved from http://www.planningforprotest.org/.

Manzini, E. (2014). Making Things Happen: Social Innovation and Design. Design Issues, 30(1), 57-66.

Manzini, E., \& Cullars, J. (1992). Prometheus of the Everyday: The Ecology of the Artificial and the Designer's Responsibility. Design Issues, 9(1), 5-20.

Manzini, E. (2008). Changing the Change Design, Visions, Proposals and Tools. Paper presented at the ALLEMANDI, Turin, Italy.

Markussen, T. (2011). The disruptive aesthetics of design activism: enacting design between art and politics. In: Making Design Matter: Nordic Design Research Conference 2011, Helsinki, 2011. Proceedings... Helsinki, p. 102-110.

Markussen, T. (2013). The Disruptive Aesthetics of Design Activism: Enacting Design between Art and Politics. Design Issues, 29(1), 38-50.

Markussen, T. (2014). Architecture \& Design versus Consumerism: How Design Activism Confronts Growth. J Des Hist 2014; 27 (4), 407-409. doi: 10.1093/jdh/epu025.

Martin, W. T. R. (2005). Between Consensus and Conflict: Habermas, Post-Modern Agonism and the Early American Public Sphere. Polity, 37(3), 365-388.

Mayer, M. (2012). In an interview conducted by Linnalabor, N. \& Tuvikene, T. Retrieved from https://inura2012tallinn.files.wordpress.com/2012/09/interview2012_mayer.pdf.

Mayer, M. (2013). First world urban activism. City, 17(1), 5-19.

Mazé, R. (2016). Design and the Future: Temporal Politics of 'Making a Difference'. Design Anthropological Futures, 37-51.

Mazé, R. (2014). Forms and Politics of Design Futures, Paper for the seminar "Ethnographies of the Possible", 2014, Aarhus, DK. Retrieved from https://kadk.dk/sites/default/files/2._maze_2014_forms_and_politics_of_design_futures.pdf.

MEDIATIONS (2016). Art \& Design Agency and Participation in Public Space. Conference at RCA, London. Retrieved from http://tr-aders.eu/conference/general-theme/ .

Melucci, A. (1996). Challenging Codes: Collective Action in the Information Age. New York: Cambridge University Press.

Melucci, A. (1995). The process of collective identity. In Volume 4 of Social movements, protest, and contention. Hank Johnston, Bert Klandermans eds, University of Minnesota, UCL Press, 41-63.

Menu, F. (2016). The Bedford Tapes: Recording The Emerging Generation. Retrieved from http://due.aaschool.ac.uk/10-2/.

Meroni, A., Fassi, D., \& Simeone, G. (2013). Design for social innovation as a form of designing activism. An action format. NESTA (ed.) Social Frontiers: The next edge of social innovation research. Available: http://www.nesta.org.uk/event/socialfrontiers [12 January 2014].Mouffe, C. (2000). Deliberative Democracy or Agonistic Pluralism Chantal Mouffe. Institute for AdvancedStudies, Vienna. Retrieved from https://www.ihs.ac.at/publications/pol/pw72.pdf.

Mouffe, C. (2007). Artistic Activism and Agonistic Spaces, ART\&RESEARCH: A Journal of Ideas, Contexts and Methods. 1(2), Summer. Retreived from http://www.artandresearch.org.uk/v1n2/mouffe.html. 
Mouffe, C. (2008). Art and Democracy. Art as an Agnostic Intervention in Public Space. Art as a Public Issue 14. Retrieved from https://readingpublicimage.files.wordpress.com/2012/04/mouffe_open14_p6-151.pdf.

Papanek, V., \& Fuller, R. B. (1972). Design for the real world: Thames and Hudson London. Retrieved from http://playpen.icomtek.csir.co.za/ acdc/education/Dr_Anvind_Gupa/Learners_Library_7_March _2007/Resources/books/designvictor.pdf.

Papanek, V. (1985). Design for the real world : Human ecology and social change /. (2nd ed., completely rev. ed.). London: Thames and Hudson.

Polletta, F. \& Jasper, J.M. (2001). Collective Identity and Social Movements. Annual Review of Sociology, 27, 283-305.

Polletta, F. (2002). Freedom Is an Endless Meeting. Democracy in American Social Movements. University of Chicago Press, Chicago.

Rancière, J. (2011). The Thinking of Dissensus: Politics and Aesthetics. In P. Bowman \& R. Stamp (Eds.), Reading Ranciere, Continuum. London and New York, 1-17.

Rancière, J. \& Rockhill, G. (2006). The Politics of Aesthetics: Bloomsbury Academic.

Rancière, J. (2010). Dissensus: On Politics and Aesthetics: Bloomsbury Publishing.

Rancière, J. (2009). The Aesthetic Dimension: Aesthetics, Politics, Knowledge. Critical Inquiry, 36(1), 1-19. doi:10.1086/606120.

Reiter, H. (2009). Participatory traditions within the Global Justice Movement. In della Porta, D.(ed.). Democracy in Social Movements. Palgrave, London, 44-72.

Simon, H. A. (1988). The Science of Design: Creating the Artificial. Design Issues, 4(1/2), 67-82.

Shove E., Watson M., Hand M. \& Ingram J. (2007). The Design of Everyday Life. Oxford, Berg.

Smith, A., Fressoli, M., Abrol, D., Arond, E., \& Ely, A. (2016). Grassroots Innovation Movements: Taylor \& Francis.

Smith, R. C., In Vangkilde, K. T., In Kjærsgaard, M. G., In Otto, T., In Halse, J., \& In Binder, T. (2016). Design anthropological futures. Bloomsbury. London.

Speculative Design in the 'Real World' (2016). Public Discussion. Retrieved from http://dvk.com.hr/interakcije/2016/10/10/speculative-design-in-the-real-world/ .

Srnicek, N., \& Williams, A. (2015). Inventing the Future: Postcapitalism and a World Without Work: Verso Books.

Stories from the front (2016). Retrieved from https://www.kickstarter.com/projects/827906908/stories-from-the-front/

Stringer, J. (2015). Against Consensus, for Dissensus. New Compass. Retrieved from http://newcompass.net/articles/against-consensus-dissensus.

Tarrow, S. (1993). Cycles of Collective Action: Between Moments of Madness and the Repertoire of Contention. Social Science History (17)2, 281-307.

Tilly, C. (1977). From mobilization to revolution. Retrieved from https://deepblue.lib.umich.edu/bitstream/handle/2027.42/50931/156.pdf?

Thorpe, A. (2008). Defining Design as Activism. Journal of Architectural Education.

Thorpe, A. (2008). Design as activism: A conceptual tool. In: Changing the Change, Turin, 2008. Proceedings... Turin, p. 1523-1535.

Thorpe, A. (2012). Architecture and Design Versus Consumerism: How Design Activism Confronts Growth. Routlege. New York.

Thorpe, A. (2014). Applying Protest Event Analysis to Architecture and Design. Social Movement Studies, 13(2), 275-295. 
UTOPIA 2016: A Year Of Imagination And Possibility (2016). Exhibition and Event series at Somerset House. London. Retrieved from https://www.somersethouse.org.uk/press/utopia-2016-yearimagination-and-possibility

Yates, L. (2014): Rethinking Prefiguration: Alternatives, Micropolitics and Goals in Social Movements, Social Movement Studies: Journal of Social, Cultural and Political Protest, DOI:10.1080/14742837.2013.870883

Walker, S., Giard, J. \& Walker, H. (2013). The Handbook of Design for Sustainability, Bloomsbury Publishing.

Weaver, S., \& Mora, R. A. (2016). Introduction: Tricksters, humour and activism. International Journal of Cultural Studies, 19(5), 479-485.

Willis, A.-M. (2013). Design, Politics and Change. In Design Philosophy Papers, (11)1, 1-6.

Wood, H. (2017). Spatial Activism. Archinect. Retrieved from http://uk.archinect.com/features/article/149989510/spatial-activism-profiling-a-new-wave-ofeuropean-architecture-collectives-and-their-spatial-manifestos.

About the Authors

Noémi Zajzon is a PhD Candidate at the Institute for Design Innovation at Loughborough University London. She researches design activism and its potential to do positive transformation. With this, she aims to develop frameworks for design encounters and sustained collaboration between activists, designers and social scientists.

Dr Erik Bohemia is the Programme Director in the Institute for Design Innovation at Loughborough University London. He led to completion an AHRC funded project exploring how new digital technologies are affecting and changing knowledge translation in New Product Development and innovation. He is interested in Design as a cultural practice and the material effects of design.

Dr Sharon Prendeville is a lecturer in design innovation at Loughborough University's London School. She researches new contexts for design and their potential to enable sustainable futures. This encompasses how sustainability manifests in urban spaces such as grassroots movements and circular cities. 